\title{
Correlation and Path Coefficient Studies in Coriander for Yield and Yield Attributing Traits
}

\author{
M.K. Shivaprasad ${ }^{1 *}$, S.K. Tehlan ${ }^{1}$, Mukesh Kumar ${ }^{2}$, V.K. Batra ${ }^{1}$ and Shikha Yashveer ${ }^{3}$ \\ ${ }^{1}$ Department of Vegetable Science, ${ }^{2}$ Department of Genetics and Plant, \\ ${ }^{3}$ Department of Molecular Biology Biotechnology and Bioinformatics, CCS Haryana \\ Agricultural University, Hisar-125004, Haryana, India \\ *Corresponding author
}

\section{A B S T R A C T}

Keywords

Coriander, Correlation, Path analysis, Seed yield.

Article Info

Accepted: 10 July 2017 Available Online: 10 September
Coriander is an annual herbaceous spice plant, a family member of Umbelliferae. In India it is grown in 4,47,000 ha area with annual production of 3,14,000 MT during 2013-14 (Anonymous, 2015). This data is shortening as compared to previous statistics with respect to production, this is because of current knowledge about its characteristic association and their effects is incomplete. To fulfill these gaps, an investigation was conducted during the 2014-15 at research farm in Hisar. Data for 11 quality traits were measured and statistically analysed. More of the traits were found having high correlation coefficients at genotypic level than the phenotypic level, demonstrating inherent associations among the characters. Seed yield per plant was associated significantly and positively with number of seeds per umbel, umbelletes per umbel, umbels per plant and secondary branches at both genotypic and phenotypic levels. Concerned to path analysis number of basal leaves, length of basal leaves, secondary branches, umbels per plant, seeds per umbellet, number of seeds per umbel and test weight exerted positive direct effect on seed yield per plant, indicating that selection based on these traits would be effective for improving seed yield in coriander germplasm lines.

\section{Introduction}

Coriander (Coriandrum sativum L.) is an important annual herbaceous seed spices, belongs to family Apiaceae (Umbelliferae) with diploid chromosomal number $2 \mathrm{n}=22$. The name coriander derived from Greek word "Koris" meaning bed-bug, because green unripened seeds give fetid bug like odor (Meena et al., 2010). It is a cross pollinated crop, originated from Western Europe and Asia (Gal et al., 2010).

In India it is mainly grown in Rajasthan, Haryana, Andhra Pradesh, Madhya Pradesh and Tamil Nadu. During 2013-14 in India it is grown in $4,47,000$ ha area with annual production of 3,14,000 MT (Anonymous, 2015).

Initiation of a breeding programme in a crop having genetic variation, it is important to collect information on the agronomically important characters to breed better varieties (Dubley and Moll, 1969). Successful breeding programme depends on traits that are related to yield, relationship among different traits and their direct and indirect effects on one 
another (Ali et al., 2003). According to Deb and Khaleque (2009) the knowledge about association and interaction of different traits with yield helps the breeder greatly in selection programme with more precession and accuracy. The intensity and direction of association of the different traits with yield were estimated with genotypic and phenotypic coefficient of correlation (Mode and Robinson, 1959). Path analysis gives exact picture of the relative importance of direct and indirect influences of the component characters towards seed yield (Bhatt, 1973).

Correlation and path analysis have been used in breeding studies in different aromatic plants (Gurubuz, 2001). This gives detailed information to identify important characters to be considered in improvement programme through selection. So, the present investigation was undertaken to estimate the relative importance of direct and indirect influences of the component traits toward seed yield, to identify important characters to be considered in crop improvement programme.

\section{Materials and Methods}

The present investigation entitled "Genetic divergence studies in coriander (Coriandrum sativum L.)" was conducted at Research Farm of the Department of Vegetable Science, Chaudhary Charan Singh Haryana Agricultural University, Hisar, during winter season of 2014-15. One hundred germplasm lines of coriander evaluated during investigation were collected from different parts of the country i.e., Uttar Pradesh, Gujarat, Haryana and Rajasthan. The experiment was laid out in a randomized block design with three replications. Hisar has semi-arid climate with cold winter and hot dry summer and is situated at $29^{\circ} 15^{\prime}$, North latitude, $75^{\circ} 72^{\prime}$ East longitude and at an elevation of $215.2 \mathrm{~m}$ above mean sea level. The rains received during July to September month is usually moderate to low and scanty. Row to row and plant to plant spacing were maintained at $50 \mathrm{~cm}$ and $20 \mathrm{~cm}$ respectively. All the agronomic package of practices was adapted to grow a healthy crop. In each replication five plants randomly selected were marked for observation. Observations were recorded for eleven characters viz., Plant height $(\mathrm{cm})$, number of basal leaves, length of basal leaves $(\mathrm{cm})$, primary branches, secondary branches, umbels per plant, umbellets per umbel, number seeds per umbellet, number of seeds per umbel, test weight $(\mathrm{g})$ and seed yield per plant $(\mathrm{g})$.

The genotypic and phenotypic correlation coefficients were calculated as per methods given by Johanson et al., (1955), Miller et al., (1958) and Singh and Chaudhury (1985). For the Path Coefficient Analysis, seed yield per plant was taken as the dependent variable while the rest characters were considered as the independent variables. The direct and indirect effects of the independent characters on seed yield per plant was estimated by simultaneous equation using the formula as applied by Deway and Lu (1959).

\section{Results and Discussion}

\section{Correlation studies}

More traits were found having high correlation coefficients at genotypic level than at phenotypic level, indicating the inherent association among the traits studied (Table 1). In agreement with the current study, higher genotypic correlation coefficients than their respective phenotypic correlation coefficients were reported by several researchers (Johnson et al., 1955; Agedew, 2006) for soybean (Glycine max L.), Adam (2006) for black cumin (Nigella sativa L.) and Wassihun (2006) for sorghum (Sorghum bicolar L.). 
Genotypic correlation analysis showed that, the seed yield per plant had significant and positive association with number of seeds per umbel (0.740), umbelletes per umbel (0.508), umbels per plant (0.487) and secondary branches (0.239). At phenotypic level the seed yield per plant had significant and positive association with number of seeds per umbel (0.677), umbelletes per umbel (0.457), umbels per plant (0.435) and secondary branches (0.199). The result is in agreement with that of Bahandari and Gupta (1991) and Tripathi et al., (2000), who reported positive association of umbels with seed yield in coriander. Jindla et al., (1985) also reported a positive association of umbels plant-1, umbellets umbel-1 and seed umbel-1 with seed yield in coriander. Singh and Mital (2003) similarly reported positive and significant association of number of umbel plant-1 with seed yield plant-1 in sweet fennel. Hence, selection of coriander plants having these features will facilitate coriander seed yield improvement.

At genotypic level, plant height was significantly positively correlated with number of basal leaves (0.920), length of basal leaves (0.913), primary branches (0.968), secondary branches (0.802), umbels per plant (0.425), umbellets per umbel (0.412), seeds per umbellet $(0.958)$ and test weight (0.908). Whereas, number of seeds per umbel (0.043) had non-significant positive association. Plant height had significant positive phenotypic correlation with number of basal leaves (0.865), length of basal leaves (0.862), primary branches $(0.884)$, secondary branches (0.688), umbels per plant (0.372), umbellets per umbel (0.358), seeds per umbellet (0.849) and test weight (0.781).Whereas, number of seeds per umbel (0.038) had non-significant positive correlation. Similar results are reported by Singh et al., (2008) in coriander.
In genotypic correlation, number of basal leaves was significantly positively correlated with length of basal leaves (0.904), primary branches $(0.864)$, secondary branches $(0.820)$, umbels per plant (0.444), umbellets per umbel (0.446), seeds per umbellet (0.839), number of seeds per umbel $(0.181)$ and test weight (0.775). Phenotypic level with length of basal leaves (0.874), primary branches (0.800), secondary branches $(0.691)$, umbels per plant (0.386), umbellets per umbel (0.389), seeds per umbellet (0.758), number of seeds per umbel (0.164) and test weight (0.679). Similar results obtained for length of basal leaves also these findings are in agreement with Dhirendra sing et al., (2006), Ali et al., (1993) in coriander. Hence, selection of coriander plants having these features will facilitate coriander seed yield improvement.

Similarly, the other characters like length of basal leaves, primary branches, secondary branches and umbels per plant recorded significant and positive association with yield contributing traits. Similar, results obtained by Dhirendra sing et al., (2006), Ali et al., (1993) in coriander. In both genotypic and phenotypic level, seeds per umbellet showed the significant and positive correlation with number of seeds per umbel $(0.163 \& 0.148)$ and test weight $(0.934 \& 0.913)$.

Number of seeds per umbel positively and significantly correlated with test weight (0.125 and 0.110 respectively) in both conditions. Similar results are reported by Shridhar et al., (1990 b) Dhirendra singh et al., (2006), Kailashchandra et al., (2000) in coriander and fenugreek. Hence, selection of coriander plants having these features will facilitate coriander seed yield improvement. 
Table.1 Genotypic (below diagonal) and phenotypic (above diagonal) correlation coefficients for yield attributing traits in coriander genotypes

\begin{tabular}{|c|c|c|c|c|c|c|c|c|c|c|c|}
\hline Characters & $\begin{array}{l}\text { Plant } \\
\text { height }\end{array}$ & $\begin{array}{c}\text { Number of } \\
\text { basal } \\
\text { leaves }\end{array}$ & $\begin{array}{c}\text { Length of } \\
\text { basal leaves }\end{array}$ & $\begin{array}{l}\text { Primary } \\
\text { branches }\end{array}$ & $\begin{array}{l}\text { Secondary } \\
\text { branches }\end{array}$ & $\begin{array}{l}\text { Umbel/ } \\
\text { plant }\end{array}$ & $\begin{array}{l}\text { Umbellets/ } \\
\text { umbel }\end{array}$ & $\begin{array}{c}\text { Number seeds/ } \\
\text { umbellet }\end{array}$ & $\begin{array}{c}\text { Number of } \\
\text { seeds/umbel }\end{array}$ & $\begin{array}{c}\text { Test } \\
\text { weight }\end{array}$ & $\begin{array}{c}\text { Seed } \\
\text { yield/plant }\end{array}$ \\
\hline Plant height & 1.000 & $0.865^{* *}$ & $0.862^{* *}$ & $0.884^{* *}$ & $0.688^{* *}$ & $0.372^{* *}$ & $0.358^{* *}$ & $0.849^{* *}$ & 0.038 & $0.781^{* *}$ & -0.033 \\
\hline Number of basal Leaves & $0.920^{* *}$ & 1.000 & $0.874^{* *}$ & $0.800^{* *}$ & $0.691^{* *}$ & $0.386^{* *}$ & $0.389^{* *}$ & $0.758^{* *}$ & $0.164^{* *}$ & $0.679^{* *}$ & 0.083 \\
\hline Length of basal leaves & $0.913^{* *}$ & $0.904^{* *}$ & 1.000 & $0.838^{* *}$ & $0.623^{* *}$ & $0.267^{* *}$ & $0.276^{* *}$ & $0.803^{* *}$ & $0.163^{* *}$ & $0.731^{* *}$ & 0.068 \\
\hline Primary branches & $0.968^{* *}$ & $0.864^{* *}$ & $0.889^{* *}$ & 1.000 & $0.702^{* *}$ & $0.379^{* *}$ & $0.375^{* *}$ & $0.951^{\text {** }}$ & 0.102 & $0.869^{* *}$ & 0.023 \\
\hline Secondary branches & $0.802^{* *}$ & $0.820^{* *}$ & $0.734^{* *}$ & $0.827^{* *}$ & 1.000 & $0.613^{* *}$ & $0.551^{* *}$ & $0.683^{* *}$ & $0.232^{* *}$ & $0.590^{* *}$ & $0.199^{* *}$ \\
\hline Umbel / plant & $0.425^{* *}$ & $0.444^{* *}$ & $0.302^{* *}$ & $0.430^{* *}$ & $0.727^{* *}$ & 1.000 & $0.976^{* *}$ & $0.414^{* *}$ & $0.374^{* *}$ & $0.347^{* *}$ & $0.435^{* *}$ \\
\hline Umbellets /umbel & $0.412^{* *}$ & $0.446^{* *}$ & $0.309^{* *}$ & $0.422^{* *}$ & $0.693^{* *}$ & $0.985^{* *}$ & 1.000 & $0.410^{* *}$ & $0.423^{* *}$ & $0.339^{* *}$ & $0.457^{* *}$ \\
\hline Number seeds /umbellet & $0.958^{* * *}$ & $0.839^{* *}$ & $0.872^{* *}$ & $0.993^{* *}$ & $0.835^{* *}$ & $0.474^{* *}$ & $0.466^{* *}$ & 1.000 & $0.148^{* *}$ & $0.913^{* *}$ & 0.078 \\
\hline Number of seeds/umbel & 0.043 & $0.181^{* *}$ & $0.176^{* *}$ & $0.111^{*}$ & $0.281^{* *}$ & $0.427^{* *}$ & $0.480^{* *}$ & $0.163^{\text {** }}$ & 1.000 & $0.110^{*}$ & $0.677^{* * *}$ \\
\hline Test weight & $0.908^{* *}$ & $0.775^{* *}$ & $0.820^{* *}$ & $0.932^{* *}$ & $0.753^{* *}$ & $0.410^{* *}$ & $0.399^{* *}$ & $0.934^{* *}$ & $0.125^{*}$ & 1.000 & 0.071 \\
\hline Seed Yield/Plant (g) & -0.034 & 0.091 & 0.073 & 0.025 & $0.239^{* *}$ & $0.487^{* *}$ & $0.508^{* *}$ & 0.085 & $0.740^{* *}$ & 0.079 & 1.000 \\
\hline
\end{tabular}

Table.2 Direct (diagonal) and indirect (off-diagonal) phenotypic path coefficients of different characters for yield per plant in 113 genotypes of coriander

\begin{tabular}{|c|c|c|c|c|c|c|c|c|c|c|c|}
\hline Characters & $\begin{array}{l}\text { Plant } \\
\text { height }\end{array}$ & $\begin{array}{c}\text { Number of } \\
\text { basal } \\
\text { leaves }\end{array}$ & $\begin{array}{c}\text { Length of } \\
\text { basal leaves }\end{array}$ & $\begin{array}{l}\text { Primary } \\
\text { branches }\end{array}$ & $\begin{array}{c}\text { Secondary } \\
\text { branches }\end{array}$ & $\begin{array}{l}\text { Umbel/ } \\
\text { plant }\end{array}$ & $\begin{array}{c}\text { Umbellets/ } \\
\text { umbel }\end{array}$ & $\begin{array}{l}\text { Number } \\
\text { seeds/ } \\
\text { umbellet }\end{array}$ & $\begin{array}{l}\text { Number of } \\
\text { seeds/umbel }\end{array}$ & Test weight & $\begin{array}{l}\text { rg with } \\
\text { yield }\end{array}$ \\
\hline Plant height & -0.28480 & 0.01462 & 0.14885 & -0.16657 & 0.00358 & 0.12856 & -0.01746 & 0.00432 & 0.02102 & 0.11522 & -0.034 \\
\hline Number of basal Leaves & -0.24624 & 0.01691 & 0.15087 & -0.15073 & 0.00360 & 0.13322 & -0.01898 & 0.00385 & 0.09027 & 0.10021 & 0.091 \\
\hline Length of basal leaves & -0.24553 & 0.01478 & 0.17264 & -0.15791 & 0.00325 & 0.09231 & -0.01343 & 0.00408 & 0.08946 & 0.10790 & 0.073 \\
\hline Primary branches & -0.25176 & 0.01353 & 0.14469 & -0.18840 & 0.00366 & 0.13103 & -0.01828 & 0.00483 & 0.05590 & 0.12815 & 0.025 \\
\hline Secondary branches & -0.19588 & 0.01168 & 0.10763 & -0.13225 & 0.00521 & 0.21178 & -0.02686 & 0.00347 & 0.12748 & 0.08699 & 0.239 \\
\hline Umbel / plant & -0.10601 & 0.00652 & 0.04615 & -0.07149 & 0.00319 & 0.34534 & -0.04756 & 0.00210 & 0.20568 & 0.05122 & 0.487 \\
\hline Umbellets /umbel & -0.10198 & 0.00658 & 0.04757 & -0.07064 & 0.00287 & 0.33690 & -0.04880 & 0.00208 & 0.23261 & 0.05008 & 0.508 \\
\hline Seeds /umbellet & -0.24183 & 0.01281 & 0.13864 & -0.17912 & 0.00355 & 0.14295 & -0.01999 & 0.00508 & 0.08134 & 0.13477 & 0.085 \\
\hline Number of seeds/umbel & -0.01089 & 0.00278 & 0.02809 & -0.01916 & 0.00121 & 0.12919 & -0.02063 & 0.00075 & 0.54978 & 0.01624 & 0.740 \\
\hline Test weight & -0.22239 & 0.01148 & 0.12626 & -0.16366 & 0.00307 & 0.11989 & -0.01655 & 0.00464 & 0.06051 & 0.14754 & 0.079 \\
\hline
\end{tabular}

Residual effect $\quad 0.46978$ 


\section{Path coefficient analysis}

The low (0.4697) residual effect was indicating high contribution of independent characters toward the dependent character i.e. seed yield per plant. The data presented in Table 2 shows that length of basal leaves exerted moderate positive direct effect $(0.17264)$ on seed yield per plant, its indirect effects were moderate positive via plant height (0.14885), number of basal leaves (0.15087), primary branches (0.14469), secondary branches (0.10763), seed per umbellet (0.13864) and test weight (0.12626). Positive negligible indirect effect was shown by umbels per plant $(0.04615)$, umbellets per umbel (0.04757) and number of seeds per umbel (0.02809). The basal leaf length had high positive direct effect on seed yield plant1. In addition, it had positive and significant associating with seed yield plant-1. This is in agreement with Diedrichesen (1996), who reported that coriander genotypes with long basal leaves had high seed yield.

Path coefficient analysis, shows that umbels per plant exerted moderate high positive direct effect (0.34534) on seed yield per plant, its indirect effects were moderate high positive via plant height $(0.12856)$, number of basal leaves (0.13322), primary branches (0.13103), secondary branches (0.21178), umbellets per umbel (0.33690), seed per umbellet (0.14295), number of seeds per umbel (0.12919) and test weight (0.11989). Negligible positive indirect effect exerted by length of basal leaves (0.09231). High positive direct effect exerted for the character number of seeds per umbel (0.54978) on seed yield. Its indirect effects were also moderate positive for secondary branches (0.12748), umbels per plant (0.20568) and umbellets per umbel (0.23261) and low positive for plant height (0.02102), number of basal leaves (0.09027), length of basal leaves (0.08946), primary branches (0.05590), number of seeds per umbel (0.08134) and test weight (0.06051). Path coefficient analysis, shows that test weight exerted moderate high positive direct effect $(0.14754)$ on seed yield per plant, its indirect effects were moderate positive via plant height $(0.11522)$, number of basal leaves (0.10021), length of basal leaves (0.10790), seed per umbellet (0.13477) and primary branches (0.12815). Negligible positive effect for secondary branches (0.08699), umbels per plant (0.05122), umbellets per umbel $(0.05008)$ and number of seeds per umbel (0.01624).

Though correlation analysis indicates the association pattern of component traits with yield, they simply represent the overall influence of particular trait on yield rather than proving cause and effect relationship. The technique of path analysis developed by Wright (1921) and demonstrated by Dewey and $\mathrm{Lu}$ (1959) facilitates in portioning the correlation coefficients into direct and indirect contribution of various characters to the yield. As such, it measures the direct influence of one variable upon others. Such information would be of great value in enabling the breeder to specifically identify important component traits of yield and utilize the genetic stock for improvement in a planned way. In the present study, path coefficient analysis was worked out using yield per plant as a dependent character and other ten selected characters as independent variables. It measures the direct as well as indirect effects of independent variables (characters) on one variable through other traits.

Among 11 characters chosen for path analysis, the results reveals that high positive direct effects were exerted by traits like number of basal leaves, length of basal leaves, secondary branches, umbels per plant, seeds per umbellet, number of seeds per umbel and test weight on seed yield per plant. Similar, results are obtained by Dhirendra singh et al., 
(2006), Prajapati et al., (2010), Kole (2004) and Jain et al., (2003) in coriander and fenugreek. Other characters viz., plant height, primary branches and umbellets per umbel showed moderate negative direct effect on seed yield per plant. These results are in accordance with findings of Singh et al., (2008), Dhirendra singh et al., (2006), Prajapati et al., (2010) in coriander and fenugreek.

\section{References}

Adam, A. 2006. Evaluation of Ethiopian black cumin (Nigella sativa L.) landraces for agronomic characters and oil contents at Adet and Woreta, North West Ethiopia. M.Sc. Thesis. Alemaya University, Alemaya, Ethiopia. 76pp.

Agedew, B. 2006. Genetic variability and association among yield and yield related traits in soybean (Glycine max L.) at Awassa and Gofa, Southern Ethiopia. M.Sc. Thesis. Alemaya University, Alemaya, Ethiopia. 83pp.

Ali, N., Javidfar, F., Elmira, J.Y. and Mirza, M.Y. 2003. Relationship among yield components and selection criteria for yield improvement in winter rape seed (Brassica napus L.). Pakistan Journal of Botany 35:167-174.

Ali, S.A.., Misra, A.K., Yadav, L.N. and Mayura, K.N., 1993. Variability and correlation studies in coriander (Coriandrum sativum L.). Intern. J. Trop. Agri., 11(1): 40-42.

Anonymous. (2015) Indian Horticulture Database 2015. www.nhb.gov.in.

Bahandari, M. and Gupta, A. 1991. Variation and association analysis in coriander. Euphytica 58:1-4.

Bhatt, G.M. 1973. Significance of path coefficient analysis in determining the nature of character association. Euphytica 22:338-343.

Deb, A.C. and Khaleque, M.A. 2009. Nature of gene action in some quantitative traits in chickpea (Cicer arietinum L.). World Journal of Agricultural Sciences 5(3):361-368.

Deway, D.R. and Lu, K.H. 1959. Correlation and path coefficient analysis of components of crested wheat grass seed production. Agronomy Journal 51: 515518.

Dhirendra Singh, Jain, S. K., Rajput, S. S., Khandewal, V. And Shiva, K. N., (2006) Genetic variation for seed yield and its components and their association in coriander germplasm. Journal of spice and aromatic Crops vol. 15(1):2529.

Diederichsen, A. 1996. Coriander (Coriandrum sativum L). Promoting the conservation and use of underutilised and neglected crops. Institute of Plant Genetics and Crop Plant Research, Gaterslbebn/ International Plant Genetic Resources Institute, Rome, Italy. 83pp.

Dubley, J.W. and Moll, R.H. 1969. Interpretation and use of estimates of heritability and genetic variances in plant breeding. Crop Science Journal 9:257-262.

Gal, G., Anwer, M.M., Meena, S.S., Mehta, R.S. and Maeria, S.P. 2010. Advances in Production technology of Coriander. National Research centre on Seed Spices Ajmer Raj. Feb 2010, pp-1-5.

Gurubuz, B. 2001. Correlation and path analysis among yield components in winter resistant coriander (Coriandrum sativum) lines. Indian Journal of Agricultural Science 71:730-732.

Jain, U.K. and Singh, D. Amrita. 2003. Correlation and path analysis for certain metric trails in coriander. Progressive Agriculture. 3(1): 86-88.

Jindla, L.N., Singh, T.H., Rang, A. and Bansal, M.L. 1985. Genetic variability and pathcoefficient analysis in coriander. Plant Genetics and Breeding 
12(2):133-136.

Johnson, H.W., Robinson, H.F. and Comstooc, R.E. 1955. Estimates of genetic and environmental variability in soybeans. Agronomy Journal 47:314318.

Kailashchandra, D. S. E. V. and Singh, D., 2000, Genetic variation and character association of seed yield and its component characters in fenugreek. Agri. Sci. Digest, 20(2): 93-95.

Kole, A. B. P. C., 2004, Genetic variability, correlation and path analysis in fenugreek (Trigonella foenum-graecum L.). J. Spices and Arom. Crops, 13(1) 44-48.

Meena, M.L.; Kumar, V.; Kumar, S.; Yadav, Y.C.; and Kumar, A. (2010). Genetic variability, heritability, genetic advance, correlation coefficient and path analysis in coriander. Indian J. Hort., 67: 242246.

Miller, P.A., Williams, J.C. and Comstock, H.F. 1958. Estimation of genetic and environmental variance in upland cotton and their implications in selection. Agronomy Journal 50:126-131.

Mode, C.J. and Rhobinson, H.F. 1959. Pleotropism and genetic divergence and covariance. Biometrics 15:518-537.

Prajapati, D. B., Ravindrababu, Y. and Prajapati, B. H., 2010, Genetic variability and character association in fenugreek (Trigonella foenum-graecum L.). J. Spices, Arom. Crops, 19(1/2):6164.
Shridar, Sulikeri, G. S. and Madalageri, B. B., 1990 b, Genetic variability in coriander (Coriandrum sativum L.). Karnataka Journal of Agricultural Sciences, 3(34): 266-269.

Singh, R.K. and Chaudhury, B.D. 1985. Biometrical methods in quantitative genetic analysis. Kalyni Publishers, New Delhi, India. 318pp.

Singh, S.P.; Katiyar, R.S.; Rai, S.K.; Yadav, M.K.; Tripathi, S.M.; Nigam, H.K. and Srivastava, J.P. 2008. Studies on genetic variability and character association in coriander grown on sodic soil. J. Medic and Aromatic Pl. Sci., 30 (2): 164-167.

Singh, Y. and Mittal, P. 2003. Correlation and path coefficient analysis in fennel (Foeniculum vulgare Mill.). Crop Research 25:111-115.

Tripathi, S.M., Srivasttava, S.B.L. and Srivastava, J.P. 2000. Variability, heritability and correlation studies in coriander (Coriandrum sativum L.). Central conference on spices and aromatic plants, 20-23 September, 2000. Calicut, Kerala, India.

Wassihun, L. 2006. Agro morphological characterization of sorghum (Sorghum bicolar L.) landraces from Metekel Zone Benishangul Gumuz region. M.Sc. Thesis. Hawasa University, Awassa, Ethiopia. 102pp.

Wright, S., 1921, Correlation and causation. J. Agril. Res., 20: 667-587.

\section{How to cite this article:}

Shivaprasad, M.K., S.K. Tehlan, Mukesh Kumar, V.K. Batra and Shikha Yashveer. 2017. Correlation and Path Coefficient Studies in Coriander for Yield and Yield Attributing Traits. Int.J.Curr.Microbiol.App.Sci. 6(9): 3593-3599. doi: https://doi.org/10.20546/ijcmas.2017.609.441 